\title{
Use of anti-citrullinated peptide (Anti-CCP) antibodies in distinguishing patients with systemic lupus erythematosus and rheumatoid arthritis
}

\author{
Harry Isbagio
}

\begin{abstract}
Abstrak
Pada awal penyakit diagnosis Artritis reumatoid (AR) sering dikacaukan dengan Lupus eritematosus sistemik (LES). Persendian terutama pada tangan dapat terserang pada kedua penyakit, sehingga pasien LES sering salah diagnosis sebagai AR. Oleh karena hasil-akhir dari kedua penyakit ini sangat berbeda, maka dibutuhkan suatu marker serologik untuk membedakan keduanya pada saat awitan penyakit. Antibodi anti-citrullinated peptide (anti-CCP) telah dilaporkan sangat spesifik pada AR. Tujuan penelitian ini untuk memastikan spesifitas antibodi anti-CCP pada AR dan kemungkinan antibodi ini dapat membedakan pasien RA dari SLE. Penelitian ini suatu studi potong-lintang pada pasien AR $(n=27)$, LES dengan artritis $(n=20)$. penyakit otoimun lain (non-reumatik, $n=8)$ dan kontrol dewasa $(n=20)$. Anti-CCP diperiksa dengan cara Elisa dan faktor-reumatoid $(F R)$ dengan uji latex. Sensitivitas dan spesifitas anti-CCP untuk diagnosis RA adalah 63.0\% dan 97.9\%, dibandingkan dengan FR yang hanya sebesar 40.7\% dan 85.4\%. Hanya 1 dewasa sehat dengan anti-CCP+, tidak satupun pasien LES maupun pasien penyakit otoimun lain yang mempunyai anti-CCP+. Nilai rerata titer anti-CCP pada dewasa sehat, penyakit otoimun lain, LES dan AR berturut-turut sebesar 1.35 $\pm 2.04,0.63 \pm 0.59,0.75 \pm 0.59$, and $38.17 \pm$ $44.22 \mathrm{RU} / \mathrm{ml}$. Terdapat perbedaan sangat bermakna di antara titer anti-CCP pada pasien AR dengan yang lainnya ( $<<0.001)$. Disimpulkan bahwa deteksi anti-CCP sangat berguna untuk diagnosis AR, dan untuk membedakan AR dari LES. (Med J Indones 2004; 13: 227-31)
\end{abstract}

\begin{abstract}
Diagnosis of Rheumatoid arthritis (RA) and systemic lupus erythematosus (SLE) can be confused in their initial stages. The joints, especially the hands, are commonly affected in both disorders, many patients with SLE are initially misdiagnosed as having RA Given that the outcome for the two diseases is diverse, it would be helpful to have serological marker to distinguish between them at onset. Anti-citrullinated peptide antibodies (anti-CCP) have recently been described as highly specific for RA. The objective of this study is to confirm the specificity of anti-CCP antibodies and to determine whether they might distinguish patients with RA from those with SLE. This study is a cross sectional study on a group of patients with RA $(n=27)$, SLE with arthritis ( $n=20)$, other autoimmune diseases (non-rheumatic diseases, $n=8)$, and healthy adults $(n=20)$. Anti-CCP was determined by a commercial Elisa test and Rheumatoid factor $(R F)$ was determined by the standard slide latex test. The sensitivity and specificity of anti-CCP for the diagnosis of $R A$ was $63.0 \%$ and $97.9 \%$ respectively, comparing with RF for RA that was $40.7 \%$ and $85.4 \%$. Only 1 healthy adult was anti-CCP+, no anti-CCP was detected from SLE and other autoimmune disease. The mean of titer anti CCP in normal healthy adult, other autoimmune diseases, SLE and RA was $1.35 \pm 2.04,0.63 \pm 0.59,0.75 \pm 0.59$, and $38.17 \pm 44.22$ RU/ml, respectively. There was a highly significant difference between the mean of titer anti CCP for RA with others diseases $(p<0.001)$. We conclude that detection of anti-CCP is very useful for the diagnosis of RA and distinguishing RA from SLE. (Med J Indones 2004; 13: 227-31)
\end{abstract}

Keywords: Rheumatoid Arthritis, Systemic Lupus Erythematosus, anti-CCP antibodies

Rheumatoid arthritis (RA) is a common rheumatic disease of uncertain aetiology with a significant level of morbidity. Despite decades of study and the development of a series of classification criteria, the diagnosis of RA remains empirical and imprecise, particularly early in the course of disease. Because

Department of Internal Medicine, Faculty of Medicine University of Indonesia/Dr.Cipto Mangunkusumo Hospital, Jakarta, Indonesia early initiation of disease modifying treatments can significantly improve long term outcomes for patients with RA, there is considerable motivation to accurately diagnose RA in patients with inflammatory arthritis early in the course of disease. ${ }^{2,3}$

RA and systemic lupus erythematosus (SLE) can be confused in their initial stages. The joints, especially the hands, are commonly affected in both disorders. Most patients with RA develop erosions within the first three years of the onset of the disease, whereas 
only $5 \%$ of patients with SLE develop erosions. ${ }^{4}$ Many patients with SLE are initially misdiagnosed as having RA. Given that the outcome for the two diseases is diverse, it would be helpful to have serological means to distinguish between them at onset.

Serological studies form a cornerstone of laboratory based patient assessment in rheumatology. The presence of rheumatoid factor (RF) was identified in patients with RA over 50 years ago; assays for RF remain one of the American College of Rheumatology (ACR) classification criteria for RA. The RF assay, in its current manifestation, remains suboptimal as a diagnostic test, as it lacks sensitivity (54-88\%) and specificity (48-92\%); it is present frequently in many other disease states, and its incidence increases with age. ${ }^{5,6}$

The shortcomings of the RF assay have provided impetus for identification of other serological assays for RA. This search has yielded serological reactivity to a number of autoantigens in subsets of patients with RA, including antikeratin antibodies (AKA) and antiperinuclear factor (APF or antifillagrin). ${ }^{7}$ Although these auto antibodies have all demonstrated lower sensitivity for diagnosis of RA than the RF , many of them are present almost exclusively in patients with RA. Analysis of AKA and APF autoantibodies showed that most of the reactivity present against these antigens was directed against citrulline residues, a post-translational modification of the amino acid arginine. This discovery led to the development of assays employing cyclic citrullinated peptides (CCP) to measure antibodies recognising citrullinated antigens as a diagnostic test for RA. Initial studies characterising the frequency of antibodies to $\mathrm{CCP}$ in mixed cohorts containing patients with rheumatic diseases, infectious diseases, and healthy patients, have shown it to be moderately sensitive $(68 \%)$ but highly specific $(98 \%)$ for RA. ${ }^{8}$ Recent data have confirmed that these antibodies are rarely if ever present in a range of other inflammatory diseases, including scleroderma, Sjögren's syndrome, and myositis. 9 Furthermore, analyses of the predictive value of CCP for RA in early inflammatory arthritis and the predictive value for functional status and radiographic erosions have suggested significant correlations. $^{9}$

The objective of this study is to confirm the specificity of anti-CCP antibodies and to determine whether they might distinguish patients with RA from those with SLE

\section{METHODS}

Patients. This study is a cross sectional study on a group of patients with RA, SLE, other autoimmune diseases (non-rheumatic diseases), and healthy subject. The sera were obtained from the Subdepartment of Rheumatology, Medical Faculty, University of Indonesia, Jakarta, Indonesia. Sera $(n=27)$ were collected from patients visiting the outpatient clinic who had been diagnosed as having definite RA according to the revised criteria of the American College of Rheumatology (ACR), and from patients who had been diagnosed as SLE according to criteria of ACR $(n=20)$. All of the SLE patients had also symptom and sign of arthritis. To further assesses specificity; we analyzed a group of serum samples from healthy adult individuals $(n=20)$ and sera from patients with other autoimmune diseases (nonrheumatic disease, $\mathrm{n}=8$ ) obtained from various clinics and hospitals. Sera were stored at $-70^{\circ} \mathrm{C}$ until used. Informed consent was obtained from all participants. The procedures followed were in accordance with the principles of the Declaration of Helsinki in 1975, as revised in 1983.

\section{Anti-CCP and Rheumatoid Factor (RF)}

Anti CCP. Blood (2-3 ml) was collected during routine venepuncture performed for periodic assessment of laboratory tests. Samples were centrifuged, and sera were divided into aliquots and stored at $-70^{\circ} \mathrm{C}$ until assayed. Samples were tested without knowing the clinical details of the patients. The presence of antiCCP was determined by a commercial ELISA test (Euroimmun, Medizinische Labordiagnostika, Germany). The manufacturer's instructions for the kit were followed, without modifications. Briefly, $100 \mu 1 /$ well of calibrators and serum samples diluted 1:100 were applied in duplicate on microtitre plates coated with synthetic peptides containing citrulline, and incubated for 60 minutes at room temperature in a humid incubation chamber. The plates were then washed three times, and $100 \mu \mathrm{l} /$ well of conjugate solution was added. After 30 minutes of incubation at room temperature, the plates were washed again three times and $100 \mu \mathrm{l} /$ well of substrate solution was added. The colour reaction was stopped after 30 minutes and the absorbency values were read immediately at $405 \mathrm{~nm}$. A control serum was used to monitor plate-to-plate variation, with the results expressed in relative units (RU). Samples with >5 RU were considered positive. 
Rheumatoid Factor. RF was determined by the standard slide latex test (Avitex, Omega Diagnostic, $\mathrm{UK}$ ) a titer $>8 \mathrm{IU} / \mathrm{ml}$ was regarded as positive.

Statistical analysis. The chi-square test was used for testing categorical data between groups, for tables with cells with small frequencies we used Fisher's exact test. Anova test was used to calculate the significance differences between mean of the titer of anti-CCP between RA patients, SLE patients, other autoimmune diseases patient and healthy control. All tests were 2 -sided, and $P$ values less than 0.05 were considered significant. To assess the utility of the various antibodies in prospectively detecting RA patients, the sensitivity, specificity, positive predictive value (PPV), and negative predictive value (NPV) were calculated using a computer program. The calculations were performed using the SPSS software package for Windows.

\section{RESULTS}

In this cross-sectional study of 75 patients dominated by rheumatic disease (Table 1), 18/75 samples tested positive for anti-CCP activity at $>5$ RU reactivity. Of these 18 patients, 17 had RA. On the other hand 18/75 samples tested positive for RF. Of these patients, 11 had RA, 4 had SLE, 1 from other autoimmune disease and 2 from healthy adults. This translates into a sensitivity and specificity of anti-CCP reactivity for the diagnosis of RA of $63.0 \%$ and $97.9 \%$ respectively (Table 2). This compared with the sensitivity and specificity of RF for RA at $40.7 \%$ and $85.4 \%$ (table 2). In the RA patients, 11/17 (64.7\%) CCP+ patients were also RF+. These tests also had independent reactivity in a significant subset of patients: 6/17 (35.5\%) patients with RA who were RF- showed reactivity to CCP and no patient with CCP-patients with RA showed reactivity to RF (Table 3 ).

We also examined the utility of combining the RF and anti-CCP diagnostic tests at optimal test performance values. Allowing the presence of either autoantibody (either RF or anti-CCP) was not increased the sensitivity for detecting RA (63\%) (Table 2) without substantially altering the specificity for RA (83.3\%) from that of RF alone. Conversely, requiring the presence of both autoantibodies (RF and anti-CCP positivity) decreased the sensitivity for diagnosis of RA to $40.7 \%$ with demonstrating a substantial increase in specificity $(100 \%)$ relative to that of antiCCP reactivity alone $(97.9 \%)$.
Although the specificity of anti-CCP for RA in our patients was $97.9 \%$, we sought to delineate the presence of anti-CCP activity in other conditions. Only 1 healthy adult was anti-CCP+, no anti-CCP was detected from SLE (with arthritis) patients and other autoimmune disease (table 1). On the other hand RF was positive in other condition e.g. 20\% for SLE, $12.5 \%$ for other autoimmune disease, and $10 \%$ for healthy adult (Table 1).

Table 1. Patient demographic by diagnosis group

\begin{tabular}{l|c|c|c}
\hline Patient group & $\begin{array}{c}\text { No.of } \\
\text { patients }\end{array}$ & $\begin{array}{c}\text { No.and \% } \\
\text { of Anti } \\
\text { CCP (+) }\end{array}$ & $\begin{array}{c}\text { No.and } \% \\
\text { of RF (+) }\end{array}$ \\
\hline $\begin{array}{c}\text { Rheumatoid } \\
\text { Arthritis (RA) } \\
\begin{array}{c}\text { Systemic Lupus } \\
\text { erythematosus } \\
\text { (SLE) }\end{array}\end{array}$ & 27 & $17(63 . \%)$ & $11(40.7 \%)$ \\
$\begin{array}{c}\text { Other autoimmune } \\
\text { disease }\end{array}$ & 8 & 0 & $4(20.0 \%)$ \\
Normal & 20 & $1(5.0 \%)$ & $2(10.0 \%)$ \\
\hline Total & 75 & $18(24 \%)$ & $18(24 \%)$ \\
\hline
\end{tabular}

Table 2. Sensitivity and specificity of anti-CCP and RF for presence of RA

\begin{tabular}{lcccc}
\hline & $\begin{array}{c}\text { Sensitivity } \\
(\%)\end{array}$ & $\begin{array}{c}\text { Specificity } \\
(\%)\end{array}$ & PPV & NPV \\
\hline CCP & $63.0 \%$ & $97.9 \%$ & $94.4 \%$ & $82.5 \%$ \\
RF & $40.7 \%$ & $85.4 \%$ & $61.1 \%$ & $71.9 \%$ \\
CCP or RF & $63.0 \%$ & $83.3 \%$ & $68.0 \%$ & $80.0 \%$ \\
CCP and RF & $40.7 \%$ & $100.0 \%$ & $100 \%$ & $75.0 \%$ \\
\hline
\end{tabular}

Table 3. Comparison of anti-CCP and RF reactivity within RA and SLE

\begin{tabular}{ccc}
\hline & $\begin{array}{c}\text { Patients with RA } \\
\text { No. }(\%)\end{array}$ & $\begin{array}{c}\text { Patients with SLE } \\
\text { No. }(\%)\end{array}$ \\
\hline $\mathrm{CCP}(+)$ & $(\mathrm{n}=17)$ & $(\mathrm{n}=0)$ \\
$\mathrm{RF}+$ & $11(64,7 \%)$ & $0(0 \%)$ \\
$\mathrm{RF}-$ & $6(35.3 \%)$ & $0(0 \%)$ \\
$\mathrm{CCP}(-)$ & $(\mathrm{n}=10)$ & $(\mathrm{n}=20)$ \\
$\mathrm{RF}+$ & $0(0 \%)$ & $4(20 \%)$ \\
$\mathrm{RF}-$ & $10(100 \%)$ & $16(80 \%)$ \\
\hline
\end{tabular}

Figure 1 presents the $95 \%$ Confident Interval of antiCCP titer for each of the disease (normal, other autoimmune disease, SLE, and RA). The mean of titer anti CCP in normal healthy adult, other autoimmune diseases, SLE and RA was $1.35 \pm 2.04,0.63 \pm 0.59$, 
$0.75 \pm 0.59$, and $38.17 \pm 44.22 \mathrm{RU} / \mathrm{ml}$, respectively. There was a highly significant difference between the mean of titer anti CCP for RA with others diseases $(\mathrm{p}<0.001)$.

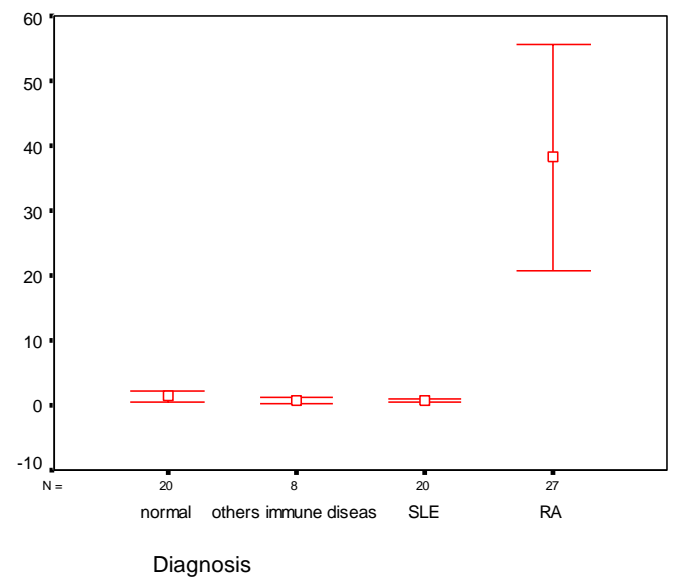

Figure 1. 95\% Confident Interval titer of anti $-C C P$ between $R A$, normal subjects and others diseases, and SLE $(p<0.05)$

\section{DISCUSSION}

Historically, the use of RF as a diagnostic tool for RA has been and remains problematic. After an initially serendipitous recognition that antibodies to $\mathrm{IgG}$ were often found in high titer in patients with RA, the sensitized sheep cell (SSC) assay was developed. This assay, cumbersome to perform, was positive in about $60 \%$ of patients with RA and infrequently in normal subjects or patients with other rheumatic diseases, and acquired the designation "Rheumatoid factor" (RF). ${ }^{10}$ This test soon helped to classify patients into "Seropositive $v$ seronegative" arthritis. However, shortcomings of the SSC assay led to the development of an assay dependent upon RF anti-Ig activity agglutinating $\operatorname{IgG}$ coated latex particles - the latex fixation assay. The latex fixation assay, easier to perform and more reproducible than the SSC assay, increased the sensitivity for RA to about $70-90 \%$ in most series. Unfortunately, the latex fixation assay lacks specificity, being positive in many patients with various chronic disease states. ${ }^{10,11}$ Although nephelometry, which also detected $\operatorname{IgM}$ anti-IgG RF, was technically more reproducible and easier to perform, it did not improve sensitivity (82\%)or specificity (92\%) for RA relative to latex agglutination. ${ }^{11}$

Concurrently, other autoantibodies have been found in patients with RA who were tested for antinuclear antibodies by the immunofluorescent (IF) technique. These assays are referred to as the APF and AKA because of their anatomical location on IF. ${ }^{12}$ When present, they demonstrate high specificity $(88-99 \%) \mathrm{f}$ or a diagnosis of RA. However, because these assays have low sensitivity $(\sim 50 \%)$ and are cumbersome to perform, their clinical application remains limited. Subsequent characterisation demonstrated that much of the reactivity to these autoantigens was contained in citrulline containing regions of the antigens. ${ }^{13}$ Antibodies to citrullinated proteins can be detected by enzyme immuno-assay, which is much more reproducible and easier to perform than the IF assays for perinuclear factor. Initial studies using citrullinated peptide as substrate demonstrated a sensitivity of $76 \%$ and a specificity of $96 \%$ for RA. Subsequently, a modified assay was developed using CCP. This assay detected IgG anti-bodies to CCP in $68 \%$ of patients with RA. Although it had a somewhat lower sensitivity than the RF test, the specificity of antiCCP for RA in that population was $96 \%$ better than that previously reported in the RF test for RA (48$92 \%)^{8}$.This represented a great clinical diagnostic improvement. Subsequent studies have confirmed the highly specific nature of anti-CCP activity in patients with RA and correlated the presence of anti-CCP with erosive disease. ${ }^{14,15,16}$

Our observation with the anti-CCP assay in 75 patients indicates a sensitivity and specificity for RA of $63 \%$ and $97.9 \%$ (not only compare with normal subjects but in comparison with patients with other rheumatic diseases/autoimmune diseases). This high sensitivity and specificity in our hands confirms the initial experience of others. We observed a very low frequency of anti-CCP in SLE, other autoimmune disease, and normal subjects. Clinical use of this assay, anti-CCP certainly brings us closer than we were with RF, particularly from the vantage of specificity. The low "false positive" rate in inflammatory arthritis in SLE with significantly increases the usefulness of anti-CCP. From a practical perspective, it would be useful to perform the RF and anti-CCP assays concurrently. Preliminary observations also suggest that the combination of testing for both $\mathrm{RF}$ and anti-CCP may be even more useful.

RA and SLE can be difficult to distinguish in the early stages. Joint deformities in patients with SLE may resemble RA despite the far lower incidence of erosions and ligament laxity. It would be desirable to have markers that readily distinguish between these two conditions. From the present data it is clear that 
patients with SLE who are RF positive are statistically significantly more likely to have a deforming major erosive arthritis. Therefore these serological markers do not readily distinguish between patients with RA and those with SLE with erosive arthropathy. However, anti-CCP antibodies were found in only two of the 10 patients with SLE with erosive disease, and were most uncommon in the other patients with SLE studied. ${ }^{17}$ Although the presence of anti-CCP antibodies is not an absolute distinguishing feature between patients with RA and erosive SLE, their presence would appear to indicate the former diagnosis. Our finding confirms the observations of Schellekens et al that anti-CCP antibodies are virtually confined to patients with RA. ${ }^{8}$ In particular, anti-CCP antibodies may be used as a helpful marker to distinguish RA from SLE. Furthermore, they may prove to be particularly useful in the small group of patients with SLE with erosive disease. ${ }^{17}$

Therefore we conclude that detection of anti-CCP is very useful for the diagnosis of RA and distinguish RA from SLE, in fact even more so than RF, because of its higher specificity. It would now be of interest to undertake a prospective study of patients with early onset synovitis, to compare their RF, anti-CCP antibodies, and HLA-DR4 status to determine just how effective these markers may be in determining long-term outcome in patients whose initial presentation with small joint arthritis may cause some diagnostic uncertainty.

\section{Acknowledgements}

We thank Dr.Linda Kurniaty Wijaya (Resident of Department of Medicine, Faculty of Medicine, University of Indonesia, Jakarta) for kindly providing the sera from patients with SLE. We also thank to Laboratorium Klinik Prodia Jakarta for providing the anti CCP Elisa assay reagents and sera from healthy adult subject.

\section{REFERENCES}

1. Anderson RJ. Rheumatoid Arthritis B. Clinical and Laboratory Features. In : Klippel JH, editors. Primer on the Rheumatic Diseases. $12^{\text {th }}$ ed. Atlanta: Arthritis Foundation: 2001.p.219-25.

2. O'Dell JR. Treating rheumatoid arthritis early a window of opportunity? Arthritis Rheum 2002; 46:283 -5.

3. Mottonen $\mathrm{T}$, Hannonen $\mathrm{P}$, Korpela $\mathrm{M}$, Nissila $\mathrm{M}$, Kautiainen $\mathrm{H}$, Ilonen $\mathrm{J}$, et al. Delay to institution of therapy and induction of remission using single-drug or combination-disease-modifying antirheumatic drug therapy in early rheumatoid arthritis. Arthritis Rheum 2002; 46:894 -8.

4. Alarcon-Segovia D, Abud-Mendoza C, Diaz-Jouanaen E, Igesias A, De Los Reyes V, Hernandez-Ortiz J. Deforming arthropathy of the hands in systemic lupus erythematosus. J Rheumatol 1991; 18:223-9.

5. Saraux A, Berthelot JM, Chales G, Le Henaff C, Mary JY, Thorel $\mathrm{V}$, et al. Value of laboratory tests in early prediction of rheumatoid arthritis. Arthritis Rheum 2002;47:155 -65.

6. Bas S, Perneger TV, Kunzle E, Vischer TL. Comparative study of different enzyme immunoassays for measurement of $\operatorname{IgM}$ and $\operatorname{IgA}$ rheumatoid factors. Ann Rheum Dis 2002; 61:505-10.

7. van Boekel MA, Vossenaar ER, van den Hoogen FH, van Venrooij WJ. Autoantibody systems in rheumatoid arthritis: specificity, sensitivity and diagnostic value. Arthritis Res 2002; 4:87-93.

8. Schellekens GA, Visser H, de Jong BA, van den Hoogen FH, Hazes JM, Breedveld FC, et al. The diagnostic properties of rheumatoid arthritis antibodies recognizing a cyclic citrullinated peptide. Arthritis Rheum 2000; 43:155 -63 .

9. Lee DM, Schur PH. Clinical utility of the anti-CCP assay in patoent with rheumatic diseases. Ann Rheum Dis 2003; 62:870-4

10. Carson DA.Rheumatoid factor. In: Kelley WN, Ruddy S, Harris ED, Sledge CB, editors. Textbook of rheumatology. Philadelphia: Saunders; 1997: 155 -63.

11. Bridges SL. Rheumatoid factor. In: Koopman WJ editors. Arthritis and allied conditions. Philadelphia: Lippincott, Williams \& Wilkins; 2001:1223 -44.

12. Young BJ, Mallya RK, Leslie RD, Clark CJ, Hamblin TJ. Anti-keratin antibodies in rheumatoid arthritis. BMJ 1979; ii: $97-9$.

13. Schellekens GA, de Jong BA, van den Hoogen FH, van de Putte LB, van Venrooij WJ. Citrulline is an essential constituent of antigenic determinants recognized by rheumatoid arthritis-specific autoantibodies. J Clin Invest 1998;101:273-81.

14. Kroot EJ, de Jong BA, van Leeuwen MA, Swinkels H, van den Hoogen FH, van 't Hof M, et al. The prognostic value of anti-cyclic citrullinated peptide antibody in patients with recent-onset rheumatoid arthritis. Arthritis Rheum 2000; 43:1831 -5.

15. Bas S, Perneger TV, Seitz M, Tiercy JM, Roux-Lombard P S, Guerne PA. Diagnostic tests for rheumatoid arthritis: comparison of anti-cyclic citrullinated peptide antibodies, anti-keratin antibodies and $\operatorname{IgM}$ rheumatoid factors. Rheumatology (Oxford) 2002;41:809-14.

16. Meyer O, Labarre $\mathrm{C}$, Dougados $\mathrm{M}$, Goupille $\mathrm{Ph}$, Cantagrel A, et al. Anticitrullinated protein/peptide antibody assays in early rheumatoid arthritis for predicting five year radiographic damage. Ann Rheum Dis 2003; 62:120-6.

17. Mediwake R, Isenberg DA, Schellekens GA, van Venrooij WJ. Use of anti-citrullinated peptide and anti-RA33 antibodies in distinguishing arthritis in patient with systemic lupus erythematosus and rheumatoid arthritis. Ann Rheum Dis 2001; 60:67-8. 